\title{
Addition of green banana biomass as partial substitute for fat and encapsulated Lactobacillus acidophilus in requeijão cremoso processed cheese
}

\author{
Franciele Pozzebon PIVETTA ${ }^{1 *}$ (D), Maritiele Naissinger da SILVA ${ }^{1}$, Bruna Lago TAGLIAPIETRA ${ }^{1}$, \\ Neila Silvia dos Santos RICHARDS ${ }^{1}$
}

\begin{abstract}
This study evaluated the effects of the addition of encapsulated Lactobacillus acidophilus and green banana biomass on the characteristics of requeijão cremoso processed cheese during the storage period of 45 days under refrigeration. The elaborated requeijões cremosos processed cheeses included addition of encapsulated Lactobacillus acidophilus as probiotic source, and green banana biomass as partial fat substitute, in a total of five treatments. Analyses were performed to evaluate probiotic viability, microbiological conditions, centesimal composition (moisture, fat, fat in dry extract, protein, ashes, carbohydrates), water activity, resistant starch, colour, texture, lipid profile and sensory acceptability. The addition of green banana biomass and fat reduction resulted in changes in the centesimal composition of the cheeses, with their moisture indexes increased and protein decreased, the F1 formulation was the only one that can be considered as low fat content and was also the one that presented higher moisture. The yellowish white coloration of the formulations was altered as a function of the composition as well as the texture parameters, F1 and F3 treatments presented the greatest changes. Probiotic viability did not differ between formulations, it only changed over time.
\end{abstract}

Keywords: functional foods; fat reduction; dairy derivative.

Practical application: New ingredients/ functional alternative for application in dairy product.

\section{Introduction}

The recent decade has witnessed a huge increase in consumer demand for food products with functional properties, in addition to being a source of essential nutrients and energy, food products are nowadays fortified with additives to improve human health (Colín-Cruz et al., 2019).

Various foods have made considerable progress in the market, and in the area of dairy products, cheese is one of the most versatile, produced throughout the world, it has a diversity of flavors, textures and shapes, is pleasing to the palate of many people and suitable for any age group (Weschenfelder et al., 2018).

According to the Technical Regulation for Identification and Quality of Requeijão, "requeijão cremoso processed cheese is the product obtained from the fusion of curd mass, cooked or uncooked, desorbed and washed, obtained by acid and/or enzymatic coagulation of the milk, optionally added of milk cream and/or butter and/or anhydrous milk fat or butter oil. The product may be added with condiments, spices and other food substances" (Brasil, 1997). Due to its versatility, the Requeijão Cremoso processed cheese has become one of the focus in researches on the production of functional and differentiated products (Vieira et al., 2014).

Consumption of green banana products is growing because it's nutritional and physiological benefits to human health (Riquette et al., 2019). Green banana is rich in starch resistant which is recognized for having positive effects on colon health (Moongngarm et al., 2014).
Consequently, many studies are being developed to evaluate its technological properties as a functional ingredient (Bezerra et al., 2013). In addition, it would also be a way to reduce the waste impacts of the fruits that are suitable for consumption, but are out of commercial standards.

Green banana biomass, cooked and processed green bananas, are tasteless and odourless, appear as an option to be used as thickeners, improving nutritional value and assuming the flavour and aroma of foods prepared with this substance (Oi et al., 2012). It can be used in the elaboration of products with reduced lipid and sugar contents (Freitas \& Tavares, 2005).

However, incorporation of probiotic bacteria is being increasingly explored in various product (Ningtyas et al., 2019). Probiotics are incorporated in food products for supplementing the activity of natural biotic population in the gastrointestinal tract (Colín-Cruz et al., 2019).

Due to these trends in food products, this study, in general, aims to develop functional requeijão cremoso processed cheese with reduced fat content by partially replacing them with green banana biomass and with addition of encapsulated Lactobacillus acidophilus. Moreover, we also aim at studying the influence of the addition of these components on the technological, physical-chemical, microbiological, functional and sensory characteristics of the cheese. 


\section{Material and methods}

\subsection{Encapsulation probiotic microorganism}

The encapsulation of the probiotic microorganism Lactobacillus acidophilus was performed using the extrusion technique, following the methodology described by Krasaekoopt et al. (2004).

\subsection{Production of the requeijão cremoso processed cheese}

For the elaboration of the requeijão cremoso processed cheese, first, the process of obtaining the base mass (curd) was carried out using the enzymatic milk coagulation method, according to the methodology described by Rodrigues (2006). Subsequently, the ingredients were weighed according to the five formulations described in Table 1, which were defined by preliminary tests performed with the product. The cheese was then processed according to Van Dender (2014).

The formulations were cooled until $40{ }^{\circ} \mathrm{C}$ under aseptic conditions for the addition of encapsulated Lactobacillus acidophilus. The products were then packed in plastic pots with a lid and stored under refrigeration at a temperature of $5 \pm 1{ }^{\circ} \mathrm{C}$.

\subsection{Physicochemical analyses}

The analyses of the requeijão cremoso processed cheese were performed at $01,15,30$ and 45 days. For the physicochemical composition of the product, it was evaluated the moisture, fat, fat content in dry extract, protein, ash and acidity, according to Normative Instruction 68/2006 (Brasil, 2006), and carbohydrates and starch, according to Association of Official Analytical Chemists (2000). AquaLab series 4TE equipment was used to evaluate the water activity.

The determination of the fatty acid profile of the requeijão cremoso processed cheese occurred through extraction, methylation and chromatographic analysis. The extraction of the lipids from the samples was performed according to the methodology proposed by Hara \& Radin (1978). Methylation was performed according to the methodology proposed by Christie (1982) and the chromatographic analysis of the samples was performed using an Agilent Technologies 6890N gas chromatograph equipped with a flame ionization detector (FID), Split injector and capillary column of fused silica, with the dimensions of $60 \mathrm{~m}$ in length, $0.25 \mathrm{~mm}$ internal diameter and $0.2 \mu \mathrm{m}$ film thickness. Nitrogen was used as the entrainment gas. The volume of sample injected was $1 \mu \mathrm{L}$. Fatty acids were identified by comparison to retention times of reference standards. The quantification of fatty acids was determined according to Visentainer (2012).

\subsection{Technological analyses}

The technological analyses carried out were instrumental texture (firmness, cohesiveness, adhesiveness and elasticity) through a texture analyser (TA-XT plus: stable micro systems, Surrey, UK, $10^{\circ} \mathrm{C}$ ) according to the methodology described by Buriti et al. (2008). Moreover, a Minolta ${ }^{\circledR}$ portable colorimeter (model CM-700d, Konica Minolta, Osaca, Japan) was used for evaluation of the colour of the requeijão cremoso processed cheese and the operating conditions were according to Okpala et al. (2010).

\subsection{Microbiological analyses}

The enumeration of viable Lactobacillus acidophilus cells were performed at 0 and 45 days, which was done according to the methodology described by Vinderola \& Reinheimer (2000), through the use of MRS agar. The samples were also submitted to hygienic-sanitary microbiological analyses of total coliforms, thermotolerant coliforms, coagulase positive Staphylococcus aureus, Salmonella and molds and yeasts according to Normative Instruction 62/2003 (Brasil, 2003).

\subsection{Sensory analysis}

For the sensory analysis, 50 untrained tasters, consumers of requeijão cremoso processed cheese participated. Acceptance test was performed for the attributes of colour, aroma, flavour, texture and global acceptance, using a structured hedonic scale of 7 points according to Lawless \& Heymann (2010). The test of purchase intention was performed with a scale of 5 points. The research was approved by the Ethics and Research Committee of the Federal University of Santa Maria, under protocol $n^{\circ} .56769116 .9 .0000 .5346$.

\subsection{Statistical analyses}

A completely randomized experimental design with factorial $2^{2}$ was used to evaluate the effect of the different components used to prepare the requeijão cremoso processed cheese on the characteristics of the same, with two independent variables and

Table 1. Composition of requeijão cremoso processed cheese formulations.

\begin{tabular}{lccccc}
\hline \multicolumn{1}{c}{ Ingredients (\%) } & Treatments/Formulations & & \\
\hline \multicolumn{1}{c}{ Mass (curd) } & F1 & F2 & F3 & F4 & \\
Pasteurized cream & 60 & 60 & 60 & 60 & F5 \\
Green banana biomass & 10 & 10 & 5 & 50 & 20 \\
Salt & 10 & 5 & 10 & 5 & 1 \\
Molten salt & 1 & 1 & 2 & 2 & 2 \\
Water & 2 & 2 & 20 & 20 & 20 \\
Encapsulated Lactobacillus acidophilus & 20 & 20 & 10 & 10 & 10 \\
\hline
\end{tabular}

${ }^{*}$ for each gram of green banana biomass, $1 \mathrm{ml}$ of water was added to each formulation. The salt and molten salt were calculated on the amount of curd mass and encapsulated Lactobacillus acidophilus were calculated on the final weight of the ready product. 
control treatment, totalling five treatments and three replicates. The independent variables were the amount pasteurized cream (fat) and green banana biomass.

The results were analysed through analysis of variance (ANOVA), Kruskal-Wallis and test for differentiation at the 5\% level of significance using BioEstat 5.0 software.

\section{Results and discussion}

Microbiological analyses of hygienic-sanitary quality of the requeijão cremoso processed cheese presented satisfactory results, with total coliforms, thermotolerant coliforms, Coagulase positive Staphylococcus aureus, Salmonella and molds and yeasts were within the limits established by current legislation (Brasil, 2001) during the 45 days of storage, which shows that the cheese was made in adequate hygienic-sanitary conditions, thus being safe for human consumption during this period.

The Lactobacillus acidophilus count during the storage period under refrigeration is shown in Table 2.

During this period there was a small reduction in the probiotic viability, approximately $1 \log$ CFU.g ${ }^{-1}$. This is due to the microorganisms being encapsulated, since the capsule provides protection to the microorganisms of the intrinsic and extrinsic agents.

Therefore, the count was adequate for the product to be called probiotic. The International Dairy Federation advises that the minimum concentration of probiotic cells should be 6-7 $\log$ CFU.g ${ }^{-1}$ at the end of shelf life of the product (Tripathi \& Giri, 2014).

It is also possible to observe that the different compositions of the requeijão cremoso processed cheese did not interfere in the probiotic viability, since the formulations did not present significant difference of viability among themselves, this may have occurred because the microorganisms were encapsulated and therefore were not in direct contact with the food matrix.

The mean values of the centesimal composition (moisture, fat, fat in dry extract, protein, ashes and carbohydrates), lactic acid and water activity of requeijão cremoso processed cheese containing or not green banana biomass and with different fat percentages are presented in Table 3.

A maximum content of $65 \%$ moisture and minimum of $55 \%$ fat in the dry extract (FDE) is recommended by the official legislation in force for requeijão cremoso processed cheese (Brasil, 1997). According to Table 3, the samples F4 and F5 (control) are within the moisture limit and only the F5 within the limit of FDE.
Treatments that received a higher amount of green banana biomass have a lower fat and protein content and higher moisture content. This is due to the fact that green banana biomass was used as a partial substitute of fat, requiring an increase of water in the formulations due to its water retention capacity, and consequently the addition of these provided a dilution of the total protein content. The moisture content of the cheese is directly related to its fat content, so that the lower the fat content, the higher the moisture content of the product should be (Silva et al., 2012). The moisture content of the requeijão cremoso processed cheese is economically important because it increases the yield of the product and directly influences the texture (Van Dender, 2014).

For this requeijão cremoso processed cheese to be considered light or with low fat content, the fat content must be reduced by at least $25 \%$, according to the classification established by the Technical Regulation regarding complementary nutritional information of the Ministry of Health (Brasil, 1998). Regarding fat in the dry extract, the lowest value obtained for this variable was the formulation $\mathrm{F} 1$, the only one with a $25 \%$ reduction, and therefore the only one that can be denominated with reduced fat content.

In relation to acidity, there was no significant difference between the treatments, but there was a significant difference $(p \leq 0.05)$ with respect to the times. The highest values obtained for the lactic acid/100g were in 30 and 45 days, that is, as time passed, the acidity increased. The increase in acidity over the storage period can be attributed to the progressive conversion of lactose to lactic acid by lactic acid bacteria activity (Ahmad et al., 2014).

The addition of green banana biomass provided an increase in water activity, since the formulations that received a higher percentage of green banana biomass presented higher water activity, and an increase in water activity was also observed over storage time.

The average amount of resistant starch during the 45 days of storage was $0.670 \mathrm{~g} / 100 \mathrm{~g}$ in F1, $0.385 \mathrm{~g} / 100 \mathrm{~g}$ in F2, $0.665 \mathrm{~g} / 100 \mathrm{~g}$ in F3, $0.400 \mathrm{~g} / 100 \mathrm{~g}$ in F4 and $0 \mathrm{~g} / 100 \mathrm{~g}$ in F5 (control), whereas the formulations that received $10 \%$ of green banana biomass (F1 and F3) had the highest $(\mathrm{p} \leq 0.05)$ resistant starch contents. These results are superior to the study proposed by Costa et al. (2017), where green banana biomass was used in yoghurt and the estimated concentrations of resistant starch obtained in the formulations that used $3 \%, 5 \%$ and $10 \%$ of green banana biomass was $0.13 \%, 0.21 \%$ and $0.43 \%$, respectively.

According to Table 4, in general, the studied requeijão cremoso processed cheese presented high values of luminosity $\left(L^{\star}\right)$, with the predominance of yellow $\left(b^{*}\right)$ in relation to the red

Table 2. Viability of L. acidophilus (log CFU.g ${ }^{-1}$ ) in requeijão cremoso processed cheese formulations stored for 45 days under refrigeration.

\begin{tabular}{|c|c|c|c|c|c|c|}
\hline \multicolumn{5}{|c|}{ Treatments } & \multicolumn{2}{|c|}{ Time (days) } \\
\hline $\mathrm{F} 1$ & $\mathrm{~F} 2$ & F3 & $\mathrm{F} 4$ & F5 & T0 & T45 \\
\hline $8.97 \pm 1.26^{a}$ & $8.81 \pm 0.89^{a}$ & $8.96 \pm 1.03^{\mathrm{a}}$ & $8.96 \pm 1.02^{\mathrm{a}}$ & $8.87 \pm 1.04^{\mathrm{a}}$ & $9.65 \pm 0.20^{\mathrm{A}}$ & $8.15 \pm 0.08^{\mathrm{B}}$ \\
\hline
\end{tabular}

Means followed by the same lowercase letter and the same capital letter in the row do not differ statistically at the $5 \%$ probability level by the Kruskal-Wallis test. F1 (10\% pasteurized cream and $10 \%$ green banana biomass); F2 (10\% pasteurized cream 5\% green banana biomass); F3 (5\% pasteurized cream and $10 \%$ green banana biomass) F4 ( $5 \%$ pasteurized cream and $5 \%$ green banana biomass); F5 (control). T0 ( 0 day shelf life); T45 (45 day shelf life). 
component $\left(\mathrm{a}^{\star}\right)$, suggesting that the yellowish white contributed to the characteristics of the products. This is in accordance with Cunha et al. (2010) who affirm that requeijão cremoso processed cheese is usually characterized by a slightly yellowish white colour.

There was a significant difference between the treatments, and the F5 treatment had the highest value obtained for the variable $L^{\star}$ and $b^{\star}$ and the lowest value for the variable $b^{\star}$. It can be inferred that the fat decrease and addition of the green banana biomass contributed to colour change by decreasing yellowish white intensity $\left(\mathrm{L}^{*} ; \mathrm{b}^{*}\right)$ and increased red intensity $\left(\mathrm{a}^{*}\right)$.
The Table 5 shows the texture parameters. Firmness and elasticity were lower in the recipes with higher percentage of green banana biomass and lower fat content (F1 and F3), showing that this ingredient and fat reduction contributed to the decrease of these parameters. These results corroborate with research conducted by Brighenti et al. (2008), who analysed samples of commercial requeijão cremoso processed cheese, and noticed that the firmness is directly proportional to the fat content. This not accordance with a study by Costa et al. (2017), who evaluated the effect of green banana addition on probiotic yogurt

Table 3. Average levels of moisture, fat, fat in DE, protein, ashes, carbohydrate, lactic acid and water activity content of each formulation/treatment of the requeijão cremoso processed cheese during 45 days of storage under refrigeration and average time.

\begin{tabular}{|c|c|c|c|c|}
\hline \multirow{2}{*}{$\begin{array}{c}\text { Parameters } \\
\text { Moisture (\%) }\end{array}$} & \multicolumn{2}{|c|}{ Average formulations } & \multicolumn{2}{|c|}{ Average storage times (T1, T15, T30 and T45 days) } \\
\hline & F1 & $67.97 \pm 0.34^{\mathrm{ab}}$ & $\mathrm{T} 1$ & $65.64 \pm 3.75^{\mathrm{a}}$ \\
\hline & $\mathrm{F} 2$ & $65.97 \pm 0.24^{\mathrm{bc}}$ & $\mathrm{T} 15$ & $65.69 \pm 2.86^{\mathrm{a}}$ \\
\hline & F3 & $69.42 \pm 0.63^{\mathrm{a}}$ & $\mathrm{T} 30$ & $65.60 \pm 3.04^{\mathrm{a}}$ \\
\hline & $\mathrm{F} 4$ & $64.29 \pm 0.32^{\mathrm{cd}}$ & $\mathrm{T} 45$ & $65.49 \pm 3.68^{\mathrm{a}}$ \\
\hline & F5 & $60.37 \pm 0.92^{\mathrm{d}}$ & & \\
\hline \multirow[t]{5}{*}{ Fat (\%) } & F1 & $11.79 \pm 0.45^{\mathrm{d}}$ & $\mathrm{T} 1$ & $16.01 \pm 4.36^{\mathrm{a}}$ \\
\hline & $\mathrm{F} 2$ & $14.89 \pm 0.62^{\mathrm{bc}}$ & $\mathrm{T} 15$ & $15.96 \pm 4.38^{\mathrm{a}}$ \\
\hline & F3 & $12.55 \pm 0.91^{\mathrm{cd}}$ & $\mathrm{T} 30$ & $16.01 \pm 4.44^{\mathrm{a}}$ \\
\hline & $\mathrm{F} 4$ & $17.53 \pm 0.24^{\mathrm{ab}}$ & $\mathrm{T} 45$ & $16.04 \pm 4.46^{\mathrm{a}}$ \\
\hline & F5 & $23.26 \pm 0.68^{\mathrm{a}}$ & & \\
\hline \multirow[t]{5}{*}{ Fat in dry extract (\%) } & $\mathrm{F} 1$ & $36.81 \pm 1.20^{\mathrm{d}}$ & $\mathrm{T} 1$ & $45.95 \pm 7.49^{\mathrm{a}}$ \\
\hline & $\mathrm{F} 2$ & $43.63 \pm 1.65^{\mathrm{bc}}$ & $\mathrm{T} 15$ & $45.91 \pm 8.70^{\mathrm{a}}$ \\
\hline & F3 & $41.03 \pm 2.65^{c}$ & $\mathrm{~T} 30$ & $45.90 \pm 8.60^{\mathrm{a}}$ \\
\hline & $\mathrm{F} 4$ & $49.11 \pm 0.81^{\mathrm{ab}}$ & $\mathrm{T} 45$ & $45.66 \pm 7.80^{\mathrm{a}}$ \\
\hline & F5 & $58.71 \pm 2.12^{\mathrm{a}}$ & & \\
\hline \multirow[t]{5}{*}{ Protein (\%) } & $\mathrm{F} 1$ & $9.13 \pm 0.73^{c}$ & $\mathrm{~T} 1$ & $9.75 \pm 0.99^{\mathrm{a}}$ \\
\hline & $\mathrm{F} 2$ & $9.57 \pm 0.48^{\mathrm{bc}}$ & $\mathrm{T} 15$ & $9.51 \pm 0.75^{\mathrm{a}}$ \\
\hline & F3 & $9.32 \pm 0.92^{c}$ & $\mathrm{~T} 30$ & $10.39 \pm 0.97^{\mathrm{a}}$ \\
\hline & $\mathrm{F} 4$ & $10.47 \pm 0.99^{\mathrm{ab}}$ & $\mathrm{T} 45$ & $9.57 \pm 0.82^{\mathrm{a}}$ \\
\hline & F5 & $10.52 \pm 0.43^{\mathrm{a}}$ & & \\
\hline \multirow[t]{5}{*}{ Ashes (\%) } & F1 & $2.62 \pm 0.54^{c}$ & $\mathrm{~T} 1$ & $2.88 \pm 0.57^{\mathrm{a}}$ \\
\hline & $\mathrm{F} 2$ & $2.86 \pm 0.12^{\mathrm{b}}$ & $\mathrm{T} 15$ & $2.97 \pm 0.17^{\mathrm{a}}$ \\
\hline & $\mathrm{F} 3$ & $2.85 \pm 0.11^{\mathrm{b}}$ & $\mathrm{T} 30$ & $2.84 \pm 0.13^{\mathrm{a}}$ \\
\hline & F4 & $3.20 \pm 0.12^{\mathrm{a}}$ & $\mathrm{T} 45$ & $2.92 \pm 0.23^{\mathrm{a}}$ \\
\hline & F5 & $2.99 \pm 0.13^{\mathrm{ab}}$ & & \\
\hline \multirow[t]{5}{*}{ Carbohydrates (\%) } & $\mathrm{F} 1$ & $8.50 \pm 1.10^{\mathrm{a}}$ & $\mathrm{T} 1$ & $5.72 \pm 2.33^{\mathrm{a}}$ \\
\hline & $\mathrm{F} 2$ & $6.71 \pm 0.86^{\mathrm{ab}}$ & $\mathrm{T} 15$ & $5.87 \pm 2.43^{\mathrm{a}}$ \\
\hline & F3 & $5.86 \pm 1.12^{\mathrm{bc}}$ & Т30 & $5.16 \pm 2.15^{\mathrm{a}}$ \\
\hline & $\mathrm{F} 4$ & $4.51 \pm 0.71^{\mathrm{cd}}$ & $\mathrm{T} 45$ & $5.99 \pm 1.96^{\mathrm{a}}$ \\
\hline & F5 & $2.87 \pm 1.18^{\mathrm{d}}$ & & \\
\hline \multirow{5}{*}{ Lactic acid $(g / 100 g)$} & $\mathrm{F} 1$ & $0.27 \pm 0.08^{\mathrm{a}}$ & $\mathrm{T} 1$ & $0.16 \pm 0.01^{\mathrm{b}}$ \\
\hline & $\mathrm{F} 2$ & $0.26 \pm 0.09^{\mathrm{a}}$ & $\mathrm{T} 15$ & $0.21 \pm 0.01^{\mathrm{b}}$ \\
\hline & F3 & $0.25 \pm 0.07^{\mathrm{a}}$ & Т30 & $0.30 \pm 0.03^{\mathrm{a}}$ \\
\hline & F4 & $0.30 \pm 0.12^{\mathrm{a}}$ & $\mathrm{T} 45$ & $0.38 \pm 0.05^{\mathrm{a}}$ \\
\hline & F5 & $0.25 \pm 0.08^{\mathrm{a}}$ & & \\
\hline \multirow[t]{5}{*}{ Water activity } & $\mathrm{F} 1$ & $0.991 \pm 0.000^{\mathrm{ab}}$ & $\mathrm{T} 1$ & $0.989 \pm 0.00^{c}$ \\
\hline & $\mathrm{F} 2$ & $0.990 \pm 0.002^{\mathrm{cb}}$ & $\mathrm{T} 15$ & $0.990 \pm 0.001^{\mathrm{bc}}$ \\
\hline & F3 & $0.992 \pm 0.000^{\mathrm{a}}$ & Т30 & $0.991 \pm 0.001^{\mathrm{ab}}$ \\
\hline & $\mathrm{F} 4$ & $0.989 \pm 0.001^{\mathrm{c}}$ & $\mathrm{T} 45$ & $0.992 \pm 0.001^{\mathrm{a}}$ \\
\hline & F5 & $0.989 \pm 0.001^{c}$ & & \\
\hline
\end{tabular}

Means followed by the same letter in the column do not differ statistically from each other at the $5 \%$ level of significance by the Kruskal-Wallis test. F1 ( $10 \%$ pasteurized cream and $10 \%$ green banana biomass); F2 (10\% pasteurized cream 5\% green banana biomass); F3 (5\% pasteurized cream and 10\% green banana biomass) F4 (5\% pasteurized cream and 5\% green banana biomass); F5 (control). T1 (1 day shelf life); T15 (15 days shelf life); T30 (30 days shelf life); T45 (45 days shelf life). 
and observed that green banana biomass caused a significant increase $(\mathrm{p}<0.05)$ in firmness.

On the other hand, as for the adhesiveness and cohesiveness parameters, the treatments that received a higher percentage of green banana biomass resulted in a higher index of these parameters, so it can be inferred that this ingredient contributed to the increase of the adhesiveness and cohesiveness.

The relations among saturated, monounsaturated and polyunsaturated fatty acids of the elaborated requeijão cremoso processed cheese containing encapsulated $L$. acidophilus and green banana biomass or not, at the 1st and 45th days of refrigerated storage, are shown in Table 6.

The fatty acids that contributed the most to the SFA index were myristic, palmitic and stearic acid, the MFA index was the oleic acid and for the PUFA index were linoleic acids and conjugated linoleic acid (CLA).

The cheeses are recognized as having a high concentration of long chain saturated fatty acids; however, they also have

Table 4. Average colour results of the requeijão cremoso processed cheese during the 45 days of storage under refrigeration.

\begin{tabular}{|c|c|c|c|c|}
\hline \multirow{2}{*}{$\frac{\text { Parameter (Colour) }}{\mathbf{L}^{*}}$} & \multicolumn{2}{|c|}{ Average treatments } & \multicolumn{2}{|c|}{ Average times } \\
\hline & $\mathrm{F} 1$ & $83.12 \pm 1.02^{c}$ & $\mathrm{~T} 1$ & $86.08 \pm 2.05^{\mathrm{a}}$ \\
\hline & $\mathrm{F} 2$ & $86.05 \pm 0.73^{\mathrm{ab}}$ & $\mathrm{T} 15$ & $85.73 \pm 2.21^{\mathrm{a}}$ \\
\hline & F3 & $83.96 \pm 0.21^{\mathrm{c}}$ & T30 & $85.25 \pm 2.16^{\mathrm{a}}$ \\
\hline & $\mathrm{F} 4$ & $85.57 \pm 0.26^{\mathrm{b}}$ & $\mathrm{T} 45$ & $84.94 \pm 2.14^{\mathrm{a}}$ \\
\hline & F5 & $88.88 \pm 0.63^{a}$ & & \\
\hline \multirow[t]{5}{*}{$a^{*}$} & $\mathrm{~F} 1$ & $1.96 \pm 0.04^{\mathrm{a}}$ & $\mathrm{T} 1$ & $1.50 \pm 0.35^{\mathrm{a}}$ \\
\hline & $\mathrm{F} 2$ & $1.45 \pm 0.04^{\mathrm{cd}}$ & $\mathrm{T} 15$ & $1.51 \pm 0.37^{\mathrm{a}}$ \\
\hline & F3 & $1.80 \pm 0.04^{\mathrm{ab}}$ & T30 & $1.53 \pm 0.40^{\mathrm{a}}$ \\
\hline & $\mathrm{F} 4$ & $1.51 \pm 0.03^{\mathrm{bc}}$ & $\mathrm{T} 45$ & $1.54 \pm 0.43^{\mathrm{a}}$ \\
\hline & $\mathrm{F} 5$ & $0.88 \pm 0.05^{\mathrm{d}}$ & & \\
\hline \multirow[t]{5}{*}{$\mathbf{b}^{*}$} & $\mathrm{~F} 1$ & $12.03 \pm 0.23^{\mathrm{cd}}$ & $\mathrm{T} 1$ & $13.31 \pm 2.20^{\mathrm{a}}$ \\
\hline & $\mathrm{F} 2$ & $12.23 \pm 0.27^{\mathrm{bc}}$ & $\mathrm{T} 15$ & $13.24 \pm 2.03^{\mathrm{a}}$ \\
\hline & $\mathrm{F} 3$ & $11.77 \pm 0.06^{\mathrm{d}}$ & T30 & $13.15 \pm 1.86^{\mathrm{a}}$ \\
\hline & $\mathrm{F} 4$ & $13.21 \pm 0.19^{\mathrm{ab}}$ & $\mathrm{T} 45$ & $13.11 \pm 1.72^{\mathrm{a}}$ \\
\hline & F5 & $16.76 \pm 0.41^{\mathrm{a}}$ & & \\
\hline
\end{tabular}

Means followed by the same letter in the column do not differ statistically at the $5 \%$ level of significance by the Kruskal-Wallis test. F1 ( $10 \%$ pasteurized cream and $10 \%$ green banana biomass); F2 (10\% pasteurized cream 5\% green banana biomass); F3 (5\% pasteurized cream and 10\% green banana biomass) F4 (5\% pasteurized cream and 5\% green banana biomass); F5 (control). T1 (1 day shelf life); T15 (15 days shelf life); T30 (30 days shelf life); T45 (45 days shelf life).

Table 5. Average texture results of the requeijão cremoso processed cheese during 45 days of storage under refrigeration.

\begin{tabular}{|c|c|c|c|c|}
\hline \multirow{2}{*}{$\begin{array}{l}\text { Parameter (texture) } \\
\text { Firmness }\end{array}$} & \multicolumn{2}{|c|}{ Average treatments } & \multicolumn{2}{|c|}{ Average times } \\
\hline & F1 & $125.88 \pm 27.68^{\mathrm{cd}}$ & $\mathrm{T} 1$ & $282.90 \pm 345.88^{\circ}$ \\
\hline & $\mathrm{F} 2$ & $287.00 \pm 381.11^{\mathrm{bc}}$ & $\mathrm{T} 15$ & $198.40 \pm 113.90^{\circ}$ \\
\hline & F3 & $102.84 \pm 21.48^{\mathrm{d}}$ & $\mathrm{T} 30$ & $244.40 \pm 138.93^{\circ}$ \\
\hline & F4 & $344.66 \pm 72.22^{\mathrm{ab}}$ & $\mathrm{T} 45$ & $285.83 \pm 173.76^{\circ}$ \\
\hline & F5 & $404.03 \pm 91.60^{\mathrm{a}}$ & & \\
\hline \multirow[t]{5}{*}{ Adhesiveness } & $\mathrm{F} 1$ & $-250.51 \pm 38.19^{a}$ & $\mathrm{~T} 1$ & $-11.77 \pm 129.83^{\circ}$ \\
\hline & $\mathrm{F} 2$ & $-404.21 \pm 8.92^{\mathrm{b}}$ & $\mathrm{T} 15$ & $-47.16 \pm 124.20$ \\
\hline & F3 & $-208.42 \pm 60.31^{\mathrm{a}}$ & T30 & $-83.81 \pm 108.93$ \\
\hline & $\mathrm{F} 4$ & $-448.04 \pm 36.78^{\mathrm{bc}}$ & $\mathrm{T} 45$ & $-03.49 \pm 115.32^{\circ}$ \\
\hline & F5 & $-496.60 \pm 45.00^{c}$ & & \\
\hline \multirow[t]{5}{*}{ Elasticity } & $\mathrm{F} 1$ & $0.56 \pm 0.02^{\mathrm{cd}}$ & $\mathrm{T} 1$ & $0.68 \pm 0.17^{\mathrm{a}}$ \\
\hline & $\mathrm{F} 2$ & $0.65 \pm 0.03^{b c}$ & $\mathrm{~T} 15$ & $0.66 \pm 0.14^{\mathrm{a}}$ \\
\hline & F3 & $0.50 \pm 0.03^{\mathrm{d}}$ & $\mathrm{T} 30$ & $0.63 \pm 0.09^{\mathrm{a}}$ \\
\hline & F4 & $0.75 \pm 0.07^{\mathrm{ab}}$ & $\mathrm{T} 45$ & $0.63 \pm 0.07^{\mathrm{a}}$ \\
\hline & F5 & $0.78 \pm 0.08^{\mathrm{a}}$ & & \\
\hline \multirow[t]{5}{*}{ Cohesiveness } & $\mathrm{F} 1$ & $0.94 \pm 0.00^{\mathrm{a}}$ & $\mathrm{T} 1$ & $0.84 \pm 0.07^{\mathrm{a}}$ \\
\hline & $\mathrm{F} 2$ & $0.80 \pm 0.01^{\mathrm{cd}}$ & $\mathrm{T} 15$ & $0.85 \pm 0.07^{\mathrm{a}}$ \\
\hline & F3 & $0.91 \pm 0.91^{\mathrm{ab}}$ & $\mathrm{T} 30$ & $0.85 \pm 0.07^{\mathrm{a}}$ \\
\hline & $\mathrm{F} 4$ & $0.78 \pm 0.01^{\mathrm{d}}$ & $\mathrm{T} 45$ & $0.86 \pm 0.06^{\mathrm{a}}$ \\
\hline & F5 & $0.81 \pm 0.02^{b c}$ & & \\
\hline
\end{tabular}

Means followed by the same letter in the column do not differ statistically at the $5 \%$ level of significance by the Kruskal-Wallis test. F1 (10\% pasteurized cream and $10 \%$ green banana biomass); F2 (10\% pasteurized cream 5\% green banana biomass); F3 (5\% pasteurized cream and 10\% green banana biomass) F4 ( $5 \%$ pasteurized cream and $5 \%$ green banana biomass); F5 (control). T1 (1 day shelf life); T15 (15 days shelf life); T30 (30 days shelf life); T45 (45 days shelf life). 
Table 6. Relation among saturated, monounsaturated and polyunsaturated fatty acids in requeijão cremoso processed cheese on day 1 and 45 of storage under refrigeration.

\begin{tabular}{|c|c|c|c|c|c|c|c|}
\hline \multirow{2}{*}{ Fatty acids } & \multicolumn{5}{|c|}{ Requeijão cremoso } & \multicolumn{2}{|c|}{ Time (days) } \\
\hline & F1 & F2 & F3 & $\mathrm{F} 4$ & F5 & $\mathrm{T} 1$ & $\mathrm{~T} 45$ \\
\hline$\%$ SFA & $69.14 \pm 0.03^{a}$ & $69.03 \pm 0.16^{a}$ & $68.77 \pm 0.12^{a}$ & $68.87 \pm 0.12^{a}$ & $69.12 \pm 0.07^{\mathrm{a}}$ & $69.04 \pm 0.14^{\mathrm{A}}$ & $68.94 \pm 0.20^{\mathrm{A}}$ \\
\hline$\%$ MFA & $28.67 \pm 0.02^{\mathrm{a}}$ & $28.77 \pm 0.23^{\mathrm{ab}}$ & $29.10 \pm 0.08^{\mathrm{a}}$ & $29.03 \pm 0.08^{\mathrm{a}}$ & $28.68 \pm 0.08^{\mathrm{a}}$ & $28.82 \pm 0.18^{\mathrm{A}}$ & $28.87 \pm 0.25^{\mathrm{A}}$ \\
\hline
\end{tabular}

Means followed by the same lowercase letter and the same capital letter in the row do not differ statistically at the 5\% probability level by the Kruskal-Wallis test. F1 (10\% pasteurized cream and $10 \%$ green banana biomass); F2 (10\% pasteurized cream 5\% green banana biomass); F3 (5\% pasteurized cream and $10 \%$ green banana biomass) F4 (5\% pasteurized cream and $5 \%$ green banana biomass); F5 (control). SFA (saturated fatty acids); MFA (monounsaturated fatty acids); PUFA (polyunsaturated fatty acids). T1 (1 day shelf life); T45 (45 days shelf life).

Table 7. Average results of the sensory evaluation regarding the acceptance test of the elaborated requeijão cremoso processed cheese.

\begin{tabular}{cccccc}
\hline Sample & Colour & Aroma & Flavour & Texture & Global appearance \\
\hline F1 & $4.62^{\mathrm{b}}$ & $4.98^{\mathrm{a}}$ & $5.24^{\mathrm{ab}}$ & $5.22^{\mathrm{a}}$ & $5.28^{\mathrm{ab}}$ \\
F2 & $5.1^{\mathrm{b}}$ & $4.68^{\mathrm{a}}$ & $4.66^{\mathrm{b}}$ & $4.12^{\mathrm{b}}$ & $4.56^{\mathrm{c}}$ \\
F3 & $4.92^{\mathrm{b}}$ & $4.88^{\mathrm{a}}$ & $5.14^{\mathrm{ab}}$ & $5.34^{\mathrm{a}}$ & $5.04^{\mathrm{bc}}$ \\
F4 & $5.12^{\mathrm{b}}$ & $4.96^{\mathrm{a}}$ & $4.9^{\mathrm{b}}$ & $4^{\mathrm{a}}$ & $4.74^{\mathrm{b}}$ \\
F5 & $5.98^{\mathrm{a}}$ & $5.12^{\mathrm{a}}$ & $5.64^{\mathrm{a}}$ & $5.42^{\mathrm{a}}$ & $5.84^{\mathrm{a}}$ \\
\hline
\end{tabular}

Means in the same column with the same overwritten did not differ significantly ( $p<0.05)$ by Tukey test (ANOVA). 1: I disliked very much, 2: I disliked much, 3: disliked, 4: indifferent, 5: I liked it, 6: I liked it much and 7: I liked it very much. F1 (10\% pasteurized cream and 10\% green banana biomass); F2 (10\% pasteurized cream 5\% green banana biomass); F3 (5\% pasteurized cream and $10 \%$ green banana biomass) F4 (5\% pasteurized cream and 5\% green banana biomass); F5 (control).

unsaturated fatty acids that are important for health, such as oleic acid and CLA. The composition of fatty acids varies according to race, season, animal diet and species, as well as cheese manufacturing processes (Matera et al., 2018).

The mean values for sensory analysis of the elaborated requeijão cremoso processed cheese are presented in Table 7.

The points attributed to the global appearance, colour, aroma, flavour and texture varied from 4.12 (indifferent) to 5.98 (liked), with the lowest and highest value being verified in the colour attribute. In this sense, the elaborated requeijão cremoso processed cheeses were considered accepted, since the grades were outside the rejection region, from 1 to 3 points. Colour is the first characteristic perceived by consumers and therefore often influences consumer preference (Mani-López et al., 2014). It can be observed, in general, that the different concentrations of green banana biomass and fat did not provide great in the acceptance of the product when compared to the control. Speranza et al. (2018) in their study developed fresh functional cream cheese and also observed that the addition of a probiotic microorganism and prebiotic ingredient did not negatively affect the product's sensory acceptability.

In relation to the purchase intention it can be affirmed that the cheeses had a good acceptance of purchase, because the greater percentages correspond to the term "would probably buy" in the majority of the formulations. The best purchase intention indices were observed in the formulations F2, F4 and F5.

\section{Conclusion}

The addition of encapsulated probiotic microorganisms in the different elaborated requeijão cremoso processed cheese provided functionality during the 45 days of storage. Green banana biomass used as a partial fat substitute resulted in a decrease in fat and protein content and an increase in moisture and water activity. The texture was influenced by fat and green banana biomass contents. The sensory analysis showed that the F1 formulation was better accepted, equating to the control. The best purchase intention indices were observed in the formulations F2, F4 and F5.

Therefore, our findings indicate that green banana biomass and encapsulated probiotic microorganisms may be a potential option as ingredients to be used in the formulation of requeijão cremoso processed cheese for dairies, adding a functional value to this product.

\section{Acknowledgements}

The present work was carried out with the support of the Coordination of Improvement of Higher Education Personnel - Brazil (CAPES) - Financing Code 001.

\section{References}

Ahmad, S. R., Pathak, V., Bhat, Z. F., \& Bukhari, S. A. (2014). Effect of sorbic acid on the storage quality of Kaladhi-an acid coagulated milk product. Journal of Food Science and Technology, 51(12), 4040-4046. http://dx.doi.org/10.1007/s13197-013-0962-6. PMid:25477678.

Association Of Official Analytical Chemists - AOAC. (2000). Official methods of analysis (17th ed.). Gaithersburg: AOAC.

Bezerra, C. V., Amante, E. R., Oliveira, D. C., Rodrigues, A. M. C., \& Silva, L. H. M. (2013). Green banana (Musa cavendishii) flour obtained in spouted bed: effect of drying on physicochemical, functional and morphological characteristics of the starch. Industrial Crops and Products, 41, 241-249. http://dx.doi.org/10.1016/j.indcrop.2012.04.035.

Brasil, Ministério da Agricultura, Pecuária e Abastecimento. (1997, September 4). Portaria no 359, de 04 de Setembro de 1998. Regulamento técnico para fixação de identidade e qualidade do requeijão ou requesón. Diário Oficial [da] República Federativa do Brasil. 
Brasil, Agência Nacional de Vigilância Sanitária. (1998, January 13). Portaria $\mathrm{n}^{\circ} 28$, de 13 de Janeiro de 1998. Aprova o uso de aditivos para alimentos com informação nutricional complementar e alimentos para fins especiais. Diário Oficial [da] República Federativa do Brasil.

Brasil, Agência Nacional de Vigilância Sanitária. (2001, January 2). Resolução ${ }^{\circ} 12$ de 2 de Janeiro 2 de 2001. Regulamento técnico sobre padrões microbiológicos para alimentos. Diário Oficial [da] República Federativa do Brasil.

Brasil, Ministério da Agricultura, Pecuária e Abastecimento. (2003, August 26). Instrução normativa nº 62, de 26 de Agosto de 2003. Oficializa os métodos analíticos oficiais para análises microbiológicas para controle de produtos de origem animal e água. Diário Oficial [da] República Federativa do Brasil.

Brasil, Ministério da Agricultura, Pecuária e Abastecimento. (2006, December 12). Instrução normativa $n^{\circ} 68$, de 12 de Dezembro de 2006. Métodos analíticos oficiais físico-químicos para controle de leite e produtos lácteos. Diário Oficial [da] República Federativa do Brasil.

Brighenti, M., Govindasamy-Lucey, S., Lim, K., Nelson, K., \& Lucey, J. A. (2008). Characterization of the rheological, textural, and sensory properties of samples of commercial US cream cheese with different fat contents. Journal of Dairy Science, 91(12), 4501-4517. http:// dx.doi.org/10.3168/jds.2008-1322. PMid:19038925.

Buriti, F. C. A., Cardarelli, H. R., \& Saad, S. M. I. (2008). Influence of Lactobacillus paracasei and inulin on instrumental texture and sensory evaluation of frees cream cheese. Brazilian Journal of Pharmaceutical Sciences, 44(1), 75-84.

Christie, W. W. (1982). A simple procedure for rapid transmethylation of glicerolipids and cholesterol esters. Journal of Lipid Research, 23(7), 1072-1075. PMid:6897259.

Colín-Cruz, M. A., Pimentel-González, D. J., Carrillo-Navas, H., AlvarezRamírez, J., \& Guadarrama-Lezama, A. Y. (2019). Co-encapsulation of bioactive compounds from blackberry juice and probiotic bactéria in biopolymeric matrices. Lebensmittel-Wissenschaft + Technologie, 110, 94-101. http://dx.doi.org/10.1016/j.lwt.2019.04.064.

Costa, E. L., Alencar, N. M. M., Rullo, B. G. S., \& Taralo, R. L. (2017). Effect of green banana pulp on physicochemical and sensory properties of probiotic yoghurt. Journal of Food Science and Technology, 37(3), 363-368. http://dx.doi.org/10.1590/1678-457x.01016.

Cunha, C. R., Dias, A. I., \& Viotto, W. H. (2010). Microstructure texture, color and sensory evaluation of a spreadable processed cheese analogue made with vegetable fat. Food Research International, 43(3), 723-729. http://dx.doi.org/10.1016/j.foodres.2009.11.009.

Freitas, M. C. J., \& Tavares, D. Q. (2005). Characterization of starch granules from bananas Musa AAA-Nanicão and Musa AAB-Terra. Food Science and Technology (Campinas), 25(02), 217-222. http:// dx.doi.org/10.1590/S0101-20612005000200005.

Hara, A., \& Radin, N. S. (1978). Lipid extraction of tissues of low toxicity solvent. Analytical Biochemistry, 90(1), 420-426. http:// dx.doi.org/10.1016/0003-2697(78)90046-5. PMid:727482.

Krasaekoopt, W., Bhandari, B., \& Deeth, H. (2004). The influence of coating material on some properties of alginate beads and survivability of microencapsulated probiotic bacteria. International Dairy Journal, 14(8), 737-743. http://dx.doi.org/10.1016/j.idairyj.2004.01.004.

Lawless, H. T., \& Heymann, H. (2010). Sensory evaluation of food: principles and practices (Food Science Text Series Book Series, no. XXIII; 2nd ed.). New York: Springer. http://dx.doi.org/10.1007/9781-4419-6488-5.

Mani-López, E., Palou, E., \& López-Malo, A. (2014). Probiotic viability and storage stability of yogurts and fermented milks prepared with several mixtures of lactic acid bacteria. Journal of Dairy Science, 97(5), 2578-2590. http://dx.doi.org/10.3168/jds.2013-7551. PMid:24745665.

Matera, J., Luna, A. S., Batista, D. B., Pimentel, T. C., Moraes, J., Kamimura, B. A., Ferreira, M. V. S., Silva, H. L. A., Mathias, S. P., Esmerino, E. A.,
Freitas, M. Q., Raices, R. S. L., Quitério, S. L., SantAna, A. S., Silva, M. C., \& Cruz, A. G. (2018). Brazilian cheeses: a survey covering physicochemical characteristics, mineral content, fatty acid profile and volatile compounds. Food Research International, 108, 18-26. http://dx.doi.org/10.1016/j.foodres.2018.03.014. PMid:29735047.

Moongngarm, A., Tiboonbun, W., Sanpong, M., Sriwong, P., Phiewtong, L., Prakitrum, R., \& Huychan, N. (2014). Resistant starch and bioactive contents of unripe banana flour as influenced by harvesting periods and its application. American Journal of Agricultural and Biological Sciences, 9(3), 457-465. http://dx.doi.org/10.3844/ajabssp.2014.457.465.

Ningtyas, D. W., Bhandari, B., Bansal, N., \& Prakash, S. (2019). The viability of probiotic Lactobacillus rhamnosus (non-encapsuled and encapsuled) in functional reduced-fat cream cheese and its textural properties during storage. Food Control, 100, 8-16. http://dx.doi. org/10.1016/j.foodcont.2018.12.048.

Oi, R. K., Tambourgi, E. B., \& Moraes, D. M. Jr. (2012). Study of the drying of green banana biomass in spray dryer. Engevista, 14(2), 165-171.

Okpala, C., Piggott, J., \& Schaschke, C. (2010). Influence of highpressure processing (HPP) on physico-chemical properties of fresh cheese. Innovative Food Science \& Emerging Technologies, 11(1), 61-67. http://dx.doi.org/10.1016/j.ifset.2009.10.003.

Riquette, R. F. R., Ginani, V. C., Leandro, E. S., Alencar, E. R., Maldonade, I. R., Aguiar, L. A., Acácio, G. M. S., Mariano, D. R. H., \& Zandonadi, R. P. (2019). Do production and storage affect the quality of green banana biomass? Lebensmittel-Wissenschaft + Technologie, 111, 190-203. http://dx.doi.org/10.1016/j.lwt.2019.04.094.

Rodrigues, F. (2006). Requeijão, fondue, specialty, processed cheese. Juiz de Fora: Templo Graphic and Publishing.

Silva, R. C. S. N., Minim, V. P. R., Simiqueli, A. A., \& Minim, L. A. (2012). Optimization of the sensorial acceptability of creamy light curd. Rural Science, 42(2), 360-366. http://dx.doi.org/10.1590/ S0103-84782012000200027.

Speranza, B., Campaniello, D., Monacis, N., Bevilacqua, A., Sinigaglia, M., \& Corbo, M. R. (2018). Funtional cream cheese supplemented with Bifidobacterium animalis subsp. Lactis DSM 10140 and Lactobacillus reuteri DSM 20016 and prebiotics. Food Microbiology, 72, 16-22. http://dx.doi.org/10.1016/j.fm.2017.11.001. PMid:29407393.

Tripathi, M. K., \& Giri, S. K. (2014). Probiotic functional foods: Survival of probiotics during processing and storage. Journal of Functional Foods, 9, 225-241. http://dx.doi.org/10.1016/j.jff.2014.04.030.

Van Dender, A. G. F. (2014). Requeijão cremoso and other processed cheeses: manufacturing technology, process control and market aspects. São Paulo: Setembro Publishing Company.

Vieira, M. C., Cavichiolo, J. R., Van Dender, M., Spadoti, L. M., Zacarchenco, P. B., Gomes, R. A. R., \& VanDender, A. G. F. (2014). Analysis of the economic viability of the production of requeijão cremoso formulations without addition of fat and with reduced sodium content. Informações Econômicas, 44(3), 36-50. Retrieved from http://www.iea.sp.gov.br/ftpiea/publicacoes/ie/2014/tec3-0614.pdf

Vinderola, C. G., \& Reinheimer, J. A. (2000). Enumeration of Lactobacillus casei in the presence of L. acidophilus, Bifidobacteria and lactic starter bacteria in fermented dairy products. International Dairy Journal, 10(4), 271-275. http://dx.doi.org/10.1016/S0958-6946(00)00045-5.

Visentainer, V. (2012). Analytical aspects of the flame ionization detector response for fatty acid esters in biodiesel and food. Nature Chemistry, 35(2), 274-279.

Weschenfelder, S., Paim, M. P., Gerhardt, C., Carvalho, H. H. C., \& Wiest, M. (2018). Antibacterial activity of different formulations of cheese and whey produced with kefir grains. Agronomic Science Journal, 49(3), 443-449. http://dx.doi.org/10.5935/1806-6690.20180050. 